\title{
Analysis of surface integrity of parts after non conventional methods of machining
}

\author{
Alena Vajdová ${ }^{1}$, Anna Mičietová ${ }^{1}$, Miroslav Neslušan ${ }^{1}$ Kamil Kolařik $^{2}$ \\ ${ }^{1}$ Faculty of Mechanical Engineering, University of Žilina, Univerzitná 8215/1, 01026 Žilina, Slovak Republic; \\ E-mail: alena.vajdova@fstroj.uniza.sk, anna.micietova@fstroj.uniza.sk,miroslav.neslusan@fstroj.uniza.sk. \\ ${ }^{2}$ ČUVT Praha, Faculty of mechanical Engineering, Trojanova 13, 12000 Praha 2, Czech Republic; \\ E-mail: kamil.kolarik@fjfi.cuvt.cz
}

This paper deals with analysis of surface integrity of steel after electro discharge machining (EDM), water jet machining, (WJM) laser beam machining (LBM) and plasma beam machining (PBM). The paper discusses surface integrity expressed in surface roughness, sample precision expressed in perpendicularity deviation as well as stress state. This study also demonstrates influence of the various non conventional methods on structure transformations and reports about sensitivity of the different non conventional methods of machining with regard to variable thickness of machined samples.

Keywords: Equation, Manufacturing Technology, Pictures, Tables, Template

Acknowledgement:

This project is solved under the financial support of VEGA agency (project n. 1/0097/12) and KEGA agency (project n. 009ŽU-4/2014, 023TUKE-4/2012 and 009ŽU-4/2014).

\section{References}

[1] MIČIETOVÁ, A. (2007). Nekonvenčné metódy obrábania - výber, využitie, perspektívy. EDIS-vydavatel'stvo ŽU, Žilina, 2007, ISBN 978-80-8070-775-0, s.72.

[2] MIČIETOVÁ, A., MAŇKOVÁ, I., VELÍŠEK, K. (2007). Top trendy v obrábaní, V. čast' - Fyzikálne technológie obrábania. MEDIA/ST, s.r.o., Žilina, 2007, ISBN 80-968954-7-2, 225 s.

[3] MAŇKOVÁ, I. (2000). Progresívne technológie, Vienala - vydavatel'stvo, Košice, pp. 275.

[4] MIČIETOVÁ, A., NESLUŠAN, M., ČILLIKOVÁ, M. (2013). Influence of surface geometry and structure after non-convetional methods of parting on the following milling operation, Manufacturing technology, Vol.13, 2013, pp. 199-204

[5] GANEV, N., ZEMAN, P., KOLǍ̌ÍK, K., BAKALOVÁ, T. (2007). Residual Stresses Distribution in Surface Layer after Milling of Steel, Manufacturing Technology, Vol. 7, 2007, pp. 10 - 18.

[6] LUKOVICS, I., MALACHOVÁ, M. (2007). Use of Laser in Engineering, Manufacturing Technology, Vol. 7, 2007, pp. $26-317$.

[7] MIČIETOVÁ, A., NESLUŠAN, M., ČILLIKOVÁ, M. (2013). Residual stresses after thermal methods parting, Machines Technologies Materials, Vol. 2, 2013, pp. 235 - 240.

[8] RAJESH, R., DEV ANAND, M. (2012). The optimization of EDM process using response surface methodology and generic algorithms, Procedia Engineering, Vol. 18, 2012, pp. 3941 - 3950.

[9] GARCÍA NAVAS, V. et. all (2008). EDM versus hard turning and grinding - comparison of residual stress and surface integrity generated in AISI O1tool steel, Journal of Material processing Technology, Vol. 195, 2008, pp. $186-194$.

[10] P - HOSSAIN, A.: A review of modelling and simulation of LBM, International Journal of Machine Tools and Manufacture, Vol. 85, pp. 135-145.

[11] MEIJER, J. (2004). LBM state of art and new opportunities, Journal of Material Processing Technology, Vol. 149, 2004, pp. 2-17.

[12] ALLEN, D.M. et. all (2009). Ion beam, focused ion beam, and plasma discharge machining, CIRP Annals Vol. 58, 2009, pp. 647-662.

[13] AXINTE, D.A. (2014). HEFJet-machining: From scientific and technological advances to niche industrial applications, CIRP Annals, Vol. 63, 2014, In Press.

[14] JUNKAR, M., JURISEVIC, B., FAJDIGA, M., GRAH, M. (2006). Fine element analysis of single-impact in abrasive water jet machining, International Journal of Impact Engineering, Vol. 32, 2006, pp. 1095-1112. 
[15] KRAUS I., GANEV N. (2004). Technické aplikace difrakční analýzy, Vydavatelství ČVUT, Praha 2004,233 s. ISBN 80-01-03099-7.

[16] KRAUS I., GANEV N. (1995). Difrakční analýza mechanických napětí. 1 vyd., Praha : ČVUT, 1995. 274 s. ISBN 80-01-01366-9.

Paper number: M201488

Copyright (C) 2014. Published by Manufacturing Technology. All rights reserved. 